\title{
THE POSSIBLE ROLE OF ADENOSINE TRIPHOSPHATE IN CHEMICAL TRANSMISSION BETWEEN THE HYPOGASTRIC NERVE TERMINAL AND SEMINAL VESICLE IN THE GUINEA-PIG
}

\author{
Hironori NAKANISHI and Hiroshi TAKEDA \\ Shionogi Research Laboratory, Shionogi \& Co, Ltd., Fukushima-ku, Osaka, Japan \\ Accepted January 13, 1973
}

\begin{abstract}
The study was designed to confirm the hypothesis that adenosine 5' triphosphate (ATP), in addition to Norepinephrine (NE) is involved in the cxcitatory transmission between the hypogastrie nerve terminal and seminal vesicle in the guinedpig. ATP produced a contraction in the isolated seminal vesicle. The pattern of contraction in response to cxogenously administered ATP resembled that of nervemediated contraction in respect of short latency, rapid rising phase and short duration. The contractions in response to both post-ganglionic hypogastric nerve stimulation and exogenously administered ATP were remarkably enhanced in the presence of NE. The potentiating effect of NE on both responses was depressed with the pre-treatment of adrenergic $\alpha$-blocking agents such as tolazoline, phenoxybenzamine, yohimbine and hydergine. The contractile responses to both hypogastric nerve stimulation and exogenously administered ATP were affected by pre-treatment with various adrenergic $\alpha$-blocking agents; tolazoline augmented both responses; phenoxybenzamine had a variable eflect on both responses; yohimbine and hydergine depressed both responses. The contractile response to NE was depressed or abolished by these adrenergic $\alpha$-blocking agents. The contractile responses to both hypogastric nerve stimulation and exogenously administered ATP were also modified by cholinergic drugs; acetylcholine $(\mathrm{ACh}$ ) enlanced both responses; physostigmine enhanced both responses as well as the response to $\mathrm{ACh}$. Atropine slightly depressed both responses and abolished the response to ACh. Atropinc also slightly depressed the nervemediated contraction in the reserpinized preparation. A relatively longer period of hypogastric nerve stimulation caused a biphasic contraction of the seminal vesicle. The initial "twitch" like contraction was resistant to reserpine-pretreatment, while the second slow rising contraction was abolished. The potentiating effect of NE on contractile responses to both hypogastric nerve stimulation and exogenously administered ATP was observed even in the reserpinized preparation. The sensitivity to NE was increased after denervation, while that to ATP was almost unaltered. The potentiating effect of NE on ATP-induced contraction was still observed in the denervated preparation. These findings are consistent with the hypothesis that ATP is involved in excitatory transmission between the hypogastric nerve and seminal vesicle in the guinea-pig. Possible role of ATP in the transmission-mechanism was discussed herein.
\end{abstract}

Despite the adrenergic nature of the hypogastric nerve innervating the smooth muscle of the guinea-pig vas deferens $(1-5)$ and seminal vesicle $(6,7)$ as demonstrated by many investigators, a persistent resistance to various adrenergic $\alpha$-blocking agents, both in vitro $(8,9)$ and in vivo (10) still remains unexplained. Swedin (11) has demonstrated a biphasic mechanical response of the guinea-pig vas deferens to hypogastric nerve stimulation over 
a relatively long period $(30 \mathrm{scc})$. The initial "twitch" like response was potentiated by adrenergic $\alpha$-blocking agents, while the second phase of contractile response was depressed or prevented. Owman and Sjostrand (12) pointed out the possibility that the short adrenergic neurons innervating reproduclive organs belong to a specific category of the sympathetic nervous system from the results of pharmacological, physiological and anatomical studies (See also Swedin (11)). Ambache and Zar (13) have argued that the motor transmission in guinca-pig vas deferens is not adrenergic. Wakade and Krusz (14) demonstrated the possible existence of another excitatory agent, in addition to norepinephrine (NE) at the post-ganglionic site of the hypogastric nerve innervating guinea-pig vas deferens.

On the other hand, adenosine 5 ' triphosphate (ATP) exists in the granulated vesicle in sympathetic nerve trunk and terminals, assockated with NE. (15). Also, Pai and Maynert (16) provided evidence for catecholamine-ATP complex in the granules. Stjärne and Liskajko (17) obscrved the spontancous release of catecholamine and ATP from the hypogastric nerve innervating the bovine vas deferens and seminal vesicle. Burnstock ct al. (18) and Su et al. (19) have demonstrated that ATP is an inhibitory transmitter in the non-adrenergic inhibitory nerve innervating the guinea-pig gut. Dumsday (20) and Burnstock et al. (21) also showed that ATP is an excitatory transmitter in atropine-resistant nerve innervating the guinea-pig urinary bladder. As several criteria must be met before a substance can be established as a neurotransmitter, the present pharmacological study was undertaken to test whether or not drugs which modify the response to nerve stimulation similarly affect the response to exogenously applied ATP which is a neurotransmitter (22).

\section{MATERIALS ANI) MFTHOISS}

Guinca-pigs, weighing $500-800 \mathrm{~g}$, were sumned by a blow on the head and bled from the common carotid arteries. The seminal vesicle was dissected out together with hypogastric nerve and immersed in Krebs-Ringer bicarbonate solution $(100 \mathrm{ml})$, aerated with a mixture of $95 \% \mathrm{O}_{3}$ and $5 \% \mathrm{CO}_{2}$ and $\mathrm{kept}$ at $37 \mathrm{C}$. The post-ganglionic fibres were stimulated with square-wave pulses (30) $\mathrm{Hz}, 1$ msec in pulse-width, sub-maximum intensity) according to Westwood and Whater's modified method (23) for the vas deferens; vir. the hypogastric nerve wats cut below the pelvis ganglion, which is located close to the prostatic end of the seminal vesicle $(24,25)$ and the peripheral end was stimulated. The isotonic contraction of the seminal vesicle in response to hypogastric nerve stimulation was recorded on a kymograph via a frontal-writing lever. For denervation, the guinea-pigs were anaesthetized with nembutal (35 mg/kg). Post-ganglionic denervation of one seminal vesicle was performed according to the modification of the method of Kasuya e1 al. (26), while the other seminal vesicle was left intact. Three weeks afier denervation, the animals were sacrificed. The sensitivity of each denervated semina! vesicle to NE and ATP was compared to the contralateral intaet vesicle. The drugs used were Acetylcholine chloride (ACh), Adenosine 5' triphosphate disodium (ATP), Atropine sulphate, Hydergine, 
Norepinephrine hydrochloride (NE), Phenoxybenzamine hydrochloride, Physostigmine hydrochloride, Reserpine (Apoplon 8 ), Tolazoline hydrochloride and Yohimbine hydrochloride.

\section{RESULTS}

1. Effect of NE on the contractile responses to hypogastric nerve stimulation and exogenously administered $A T P$

In the guinea-pig seminal vesicle, a rapid contraction of short latency (within $1 \mathrm{sec}$ ) was elicited by the hypogastric nerve stimulation. The nerve-mediated contraction could not be maintained during the repetitive stimulation and started to fade within several seconds (Fig. 1A). A relatively longer period (30 sec) of hypogastric nerve stimulation produced biphasic mechanical response of the seminal vesicle; viz the initial rapid "twitch" like contraction was followed by the second, slower phase of contraction (Fig. 1B). Thus, the present study confirmed that the finding of Swedin regarding the vas deferens (11) also holds true for the seminal vesicle. An administration of more than $10^{-7} \mathrm{~g} / \mathrm{ml}$ ATP caused a rapid "twitch" like contraction with short latency (within $1 \mathrm{sec}$ ) of the guinea-pig scminal vesicle. The ATP-induced contraction could not be maintained and faded rapidly within several seconds after application. The amplitude of contraction induced by ATP ( $5 \times$ $10^{-6} \mathrm{~g} / \mathrm{ml}$ ) was less than that of the nerve-mediated contraction (Fig. 1C), with the average

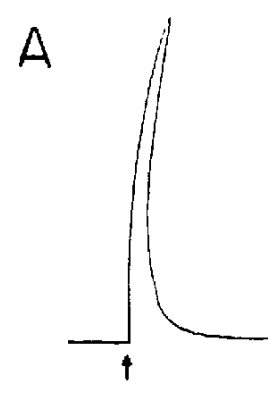

NS. 3 s

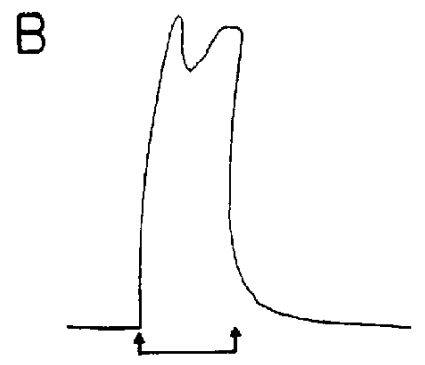

NS. $30 \mathrm{~s}$

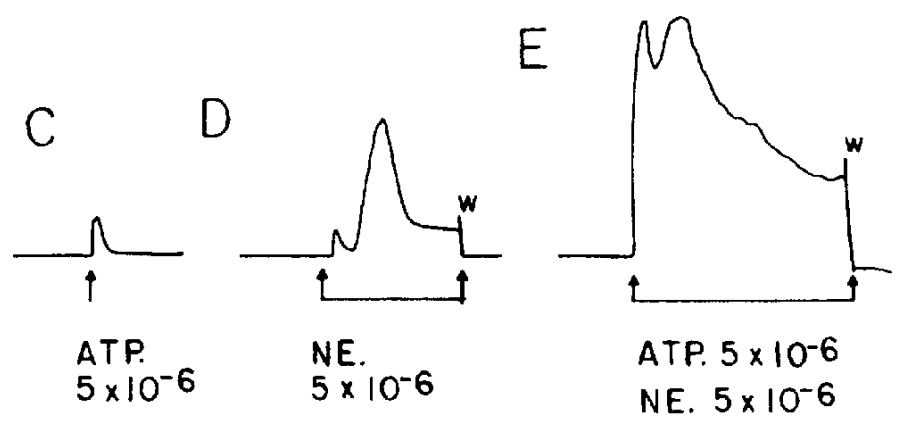

Fig. 1. Contraction of the isolated guinea-pig's seminal vesicle in response to relatively shorter periods $(3 \mathrm{sec})(\mathbf{A})$, and longer periods $(30 \mathrm{sec})(B)$ of hypogastric nerve stimulation. The contractile responses to exogenously administered ATP $\left(5 \times 10^{-6} \mathrm{~g} / \mathrm{ml}\right)$ (C), NE $\left(5 \times 10^{-6} \mathrm{~g} / \mathrm{ml}\right)$ (D), and combined, unmixed administration of ATP $\left(5 \times 10^{-6} \mathrm{~g} / \mathrm{ml}\right)$ and $\mathrm{NE}\left(5 \times 10^{-6}\right.$ $\mathrm{g} / \mathrm{ml}$ ) (E). Note the similarity between $\mathbf{B}$ and $\mathbf{E}$. 
amplitude of ATP-induced contraction being $19.2 \ldots 4.5 \%$ (22 experiments) of that of nervemediated contraction. On the contrary, administration of NE, more than $10^{-\tau} \mathrm{g} / \mathrm{ml}$, produced a very slow phasic contraction of the guinea-pig seminal vesicle with a long latency $(3-20 \mathrm{sec})$ and gradual decline (Fig. 1D). Combined administration of ATP $\left(10^{-6}\right.$ to $\left.5 \times 10^{-6} \mathrm{~g} / \mathrm{ml}\right)$ and $N E\left(10^{-6}\right.$ to $\left.5 \times 10^{-6} \mathrm{~g} / \mathrm{ml}\right)$, using separate syringes, produced a biphasic contraction; viz, an initial strong, rapid, "twitch" like contraction, followed by a slower phasic contraction (Fig. 1E). The pattern of the contraction induced by the combined administration of ATP and NE resembled that of the contraction induced by a longer period $(30 \mathrm{sec})$ of hypogastric nerve stimulation.

Contractile responses of the guinea-pig scminal vesicle to both hypogastric nerve stimulation and exogenously administered ATP $\left(10^{-8}\right.$ to $\left.10^{-5} \mathrm{~g} / \mathrm{ml}\right)$ were remarkably potentiated in the presence of NE $\left(10^{-8}\right.$ to $\left.10^{-5} \mathrm{~g} / \mathrm{ml}\right)$ (Fig. 2). The nerve-mediated contraction and ATP $\left(10^{-6} \mathrm{~g} / \mathrm{ml}\right)$-induced contraction was augmented $179.1 \mid 41.6 \%$ (10 expcriments) and $1055.7 \ldots 324.4 \%\left(13\right.$ experiments) in the presence of $\mathrm{NE}\left(10^{-6} \mathrm{~g} / \mathrm{ml}\right)$, respectively (Table 1). Also, in the presence of NE, the dose-response curve of ATP was significantly shifted to the left and the maximum response was elevated, indicating synergisms between ATP and NE (Fig. 2). The potentiating effect of NE on contractile responses to both hypogastric nerve stimulation and exogenously administered ATP promptly disappeared after washing-out the preparation. Contractile responses of the seminal vesicle to both hypogastric nerve stimulation and exogenously administered NE $\left(10^{-5}\right.$ to $\left.10^{-6} \mathrm{~g} / \mathrm{ml}\right)$ were hardly affected by pretreatment of ATP $\left(10^{-7}\right.$ to $\left.10^{-5} \mathrm{~g} / \mathrm{ml}\right)$, which had been alpplied 0.5 to 3 min before. It is assumed that the ATP hydrolyses rapidly in the tissues.
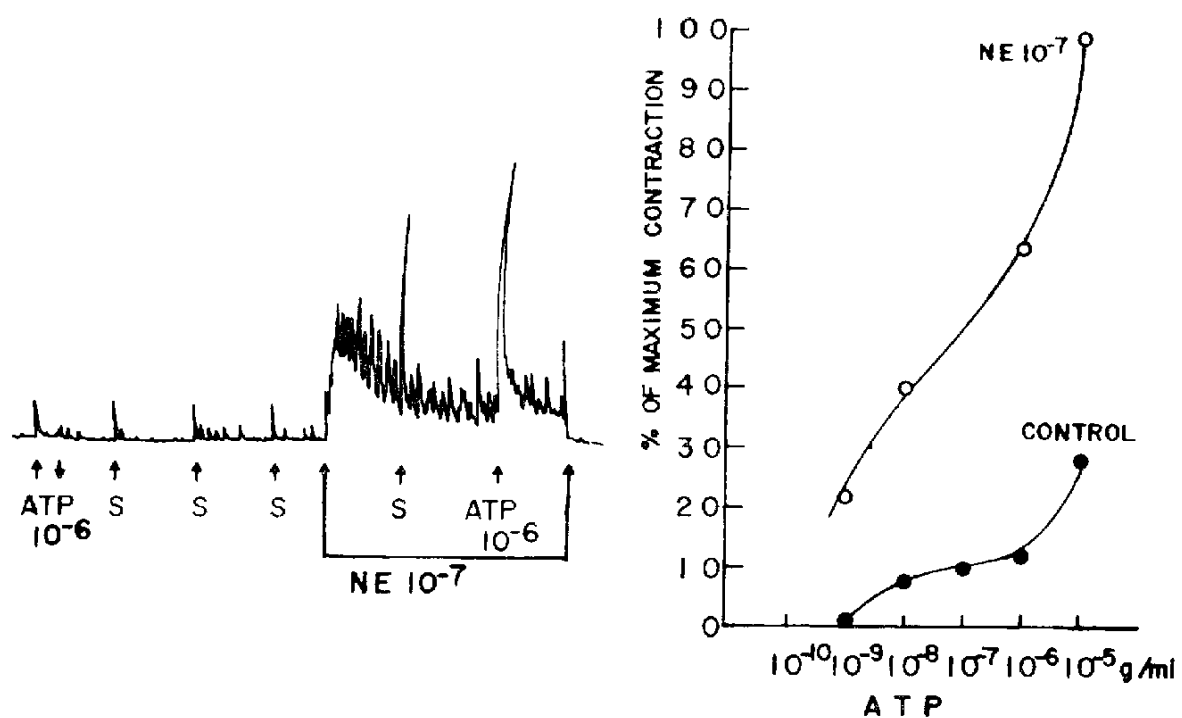

FIG. 2. Left; Potentiating effect of NE $\left(10^{-7} \mathrm{~g} / \mathrm{ml}\right)$ on contractile responses of the isolated guinea-pig's seminal vesicle to hypogastric nerve stimulation (S) and exogenously administered ATP $\left(10^{-1 \mathfrak{g}} \mathrm{g} / \mathrm{ml}\right)$. Right ; The dose-response curve of ATP on the isolated seminal vesicle. (O) control ; $(0)$ in the presence of $\mathrm{NE}\left(10^{-7} \mathrm{~g} / \mathrm{ml}\right)$. Note the synergism between ATP and NE. 
TABLE 1. Effects of various autonomic agents on the contractile responses of the isolated guinea-pig's seminal vesicle to hypogastric nerve stimulation and exogenously administered ATP $\left(10^{-15}\right.$ giml $\}$.

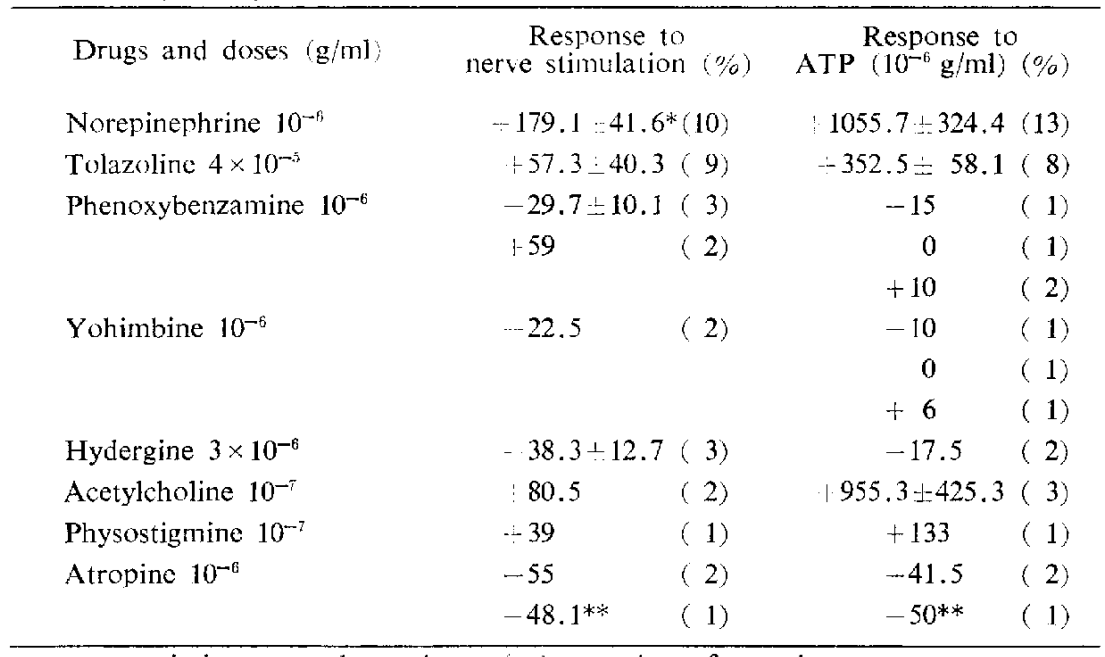

$\dashv$ : potentiation, - : depression, ( ) : number of experiments

* : standard error, **: in reserpinized animal

2. Effects of various adrenergic $\alpha$-blocking agents on the contracille responses to hypogastric nerve stimulation and exogenously administered ATP

a) Tolazoline: The administration of tolazoline $\left(2 \times 10^{-5}\right.$ to $\left.10^{-4} \mathrm{~g} / \mathrm{ml}\right)$ produced a slight elevation of muscular tone. The contractile response to exogenously administed NE $\left(10^{-6} \mathrm{~g} / \mathrm{ml}\right)$ was abolished in the presence of tolazoline $\left(2 \times 10^{-5}\right.$ to $\left.10^{-4} \mathrm{~g} / \mathrm{ml}\right)$, while response to exogenously administered ATP $\left(10^{-6} \mathrm{~g} / \mathrm{ml}\right)$ was augmented. In the presence of tolazoline $\left(4 \times 10^{-5} \mathrm{~g} / \mathrm{ml}\right)$, the contractile responses of the seminal vesicle to hypogastric nerve stimulation and exogenously administered ATP $\left(10^{-6} \mathrm{~g} / \mathrm{ml}\right)$ were augmented $57.3 \pm$ $40.3 \%$ ( 9 experiments) and $352.5-58.1 \%$ ( 8 experiments), respectively (Table 1), Boyd ct al. (8) have also reported the augmenting effect of tolazoline on the contractile response of the guinea-pig vas deferens to hypogastric nerve stimulation. The effects of tolazoline disappeared after washing out the preparation.

b) Phenoxybenzamine: The administration of phenoxybenzamine $\left(10^{-8}\right.$ to $10^{-6}$ $\mathrm{g} / \mathrm{ml}$ ) had almost no effect on the muscular tone of the seminal vesicle. The contractile response to cxogenously administered NE $\left(10^{-6} \mathrm{~g} / \mathrm{ml}\right)$ was prevented by treatment of phenoxybenzamine (more than $10^{-7} \mathrm{~g} / \mathrm{ml}$ ). The effect of phenoxybenzamine $\left(10^{-7}\right.$ to $10^{-6}$ $\mathrm{g} / \mathrm{ml}$ ) on the contractile response to post-ganglionic hypogastric nerve stimulation was however variable; vic. 3 cases out of 5 showed a slight depression while others showed a slight potentiation. The potentiating effect of phenoxybenzamine on the nerve-mediated contraction of the guinea-pig vas deferens has also been reported by Boyd et al. (8), Bhagat and Zeidman (27) and Wakade and Krusz (14). The effect of phenoxybenzamine $\left(10^{-6}\right.$ $\mathrm{g} / \mathrm{ml})$ on ATP $\left(10^{-6} \mathrm{~g} / \mathrm{ml}\right)$-induced contraction was also variable; one case out of 4 showed slight depression, 2 cases out of 4 showed slight potentiation and one case showed no effect (Table 1). 
c) Yohimbine: The administration of yohimbine $\left(10^{-6}\right.$ to $\left.10^{-5} \mathrm{~g} / \mathrm{ml}\right)$ had almost no effect on the muscular tone of the seminal vesicle. The contractile response to exogenously administered NE $\left(10^{-f i} \mathrm{~g} / \mathrm{ml}\right)$ was prevented by treatment of yohimbine (more than $\left.10^{-6} \mathrm{~g} / \mathrm{ml}\right)$. Also, the contractile response to hypogastric nerve stimulation $\left(10^{-6}\right.$ $\mathrm{g} / \mathrm{ml}$ ) was depressed $22.5 \%$ (2 experiments). The effect of yohimbine $\left(10^{-6} \mathrm{~g} / \mathrm{ml}\right)$ on the contractile response to exogenously administered ATP $\left(10^{-6} \mathrm{~g} / \mathrm{ml}\right)$ was however variable (Table 1).

d) Hydergine: The administration of hydergine $\left(3 \times 10^{-7}\right.$ to $\left.3 \times 10^{-6} \mathrm{~g} / \mathrm{ml}\right)$ had no effect on the muscular tone of the seminal vesicle. The contractile response to exogenously administered NE $\left(10^{-6}\right.$ to $\left.2 \times 10^{-6} \mathrm{~g} / \mathrm{ml}\right)$ was prevented by treatment with hydergine $(3 \times$ $\left.10^{-6} \mathrm{~g} / \mathrm{ml}\right)$. Contractile responses to both hypogastric nerve stimulation and exogenously administered ATP $\left(10^{-6} \mathrm{~g} / \mathrm{m} !\right)$ were slightly depressed $38.3+12.7 \%$ (3 experiments) and $17.5 \%$ ( 2 experiments), respectively, with treatment of hydergine $\left(3 \times 10^{-6} \mathrm{~g} / \mathrm{ml}\right)$. The depressive effect of hydergine disappeared after washing out the preparation.

3. Effects of cholinergic drugs on the contractile responses to hypogastric nerve stimulation and exogenously administered ATP

a) Acetylcholine: The administration of $\mathrm{ACh}$ (more than $10^{-8} \mathrm{~g} / \mathrm{ml}$ ) caused a strong contraction of the seminal vesicle. The pattern of ACh-induced contraction was similar to that of NE-induced contraction. The contractile responses to both hypogastric nerve stimulation and exogenously administered ATP $\left(10^{-6} \mathrm{~g} / \mathrm{ml}\right)$ were remarkably augmented in the presence of $\mathrm{ACh}$ (more than $10^{-8} \mathrm{~g} / \mathrm{ml}$ ) (Fig. 3). In the presence of $\mathrm{ACh}\left(10^{-7} \mathrm{~g}\right.$ ) $\mathrm{ml})$, the nerve-mediated contraction and ATP $\left(10^{-6} \mathrm{~g} / \mathrm{ml}\right)$-induced contraction were augmented $80.5 \%$ (2 experiments) and $955.3 \pm 425.3 \%$ ( 3 experiments), respectively. The augmenting effect of $\mathrm{ACh}$ disappeared after washing out the preparation.
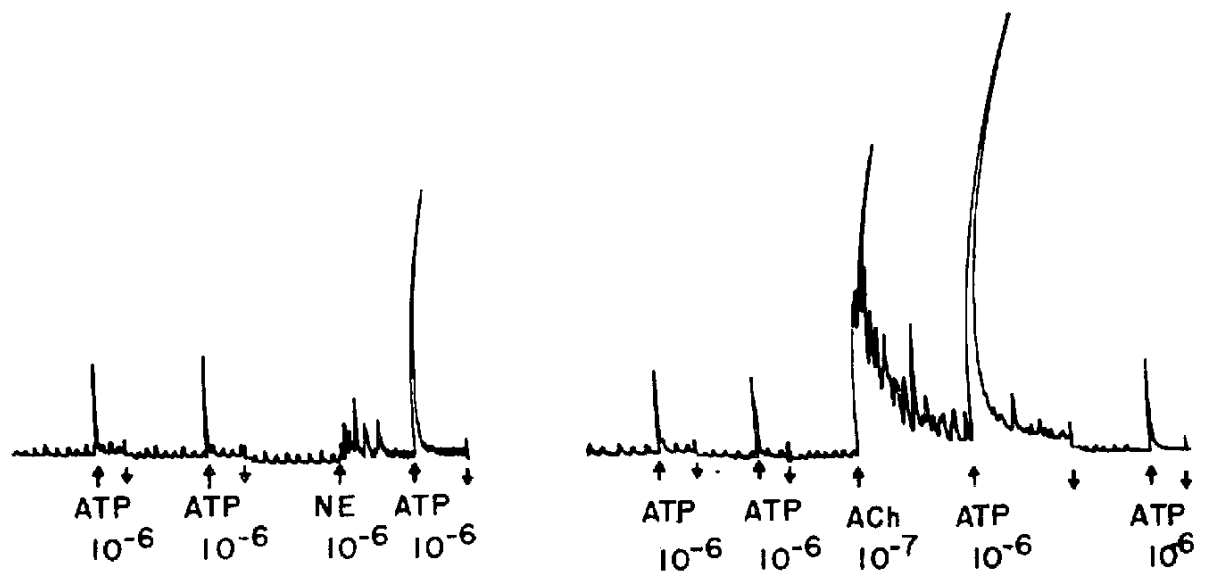

+ WASH-OUT

FIG. 3. Potentiating effect of $\mathrm{NE}\left(10^{-6} \mathrm{~g} / \mathrm{ml}\right)$ (left) and $\mathrm{ACh}\left(10^{-7} \mathrm{~g} / \mathrm{ml}\right)$ (right) on the contractilc response of the isolated guinea-pig's seminal vesicle to exogenously administered ATP $\left(10^{-6} \mathrm{~g} / \mathrm{ml}\right)$. 
b) Physostigmine: The contractile response of the seminal vesicle to exogenously administered $\mathrm{ACh}\left(10^{-7}\right.$ to $\left.2 \times 10^{-7} \mathrm{~g} / \mathrm{ml}\right)$ was considerably augmented by treatment with physostigmine $\left(10^{-16}\right.$ to $\left.2 \times 10^{-6} \mathrm{~g} / \mathrm{ml}\right)$. The contractions in response to both hypogastric nerve stimulation and exogenously administered ATP $\left(10^{-6} \mathrm{~g} / \mathrm{ml}\right)$ were slightly augmented by treatment of physostigmine $\left(10^{-6} \mathrm{~g} / \mathrm{ml}\right)$. In the presence of physostigmine $\left(10^{-6} \mathrm{~g} / \mathrm{ml}\right)$, the nerve-mediated and ATP $\left(10^{-6 i} \mathrm{~g} / \mathrm{ml}\right)$-induced contractions were augmented $39 \%(1$ experiment) and $133 \%$ (1 experiment), respectively (Table 1). The augmenting effect of physostigmine disappeared after washing out the preparation. The augmenting effect of physostigmine on the contractile response of the guinea-pig vas deferens has been reported by Boyd et al. (8) and Della Bella et al. (28) and Bhargava et al. (29).

c) Atropine: The administration of atropine $\left(10^{-7}\right.$ to $\left.10^{-6} \mathrm{~g} / \mathrm{ml}\right)$ had almost no effect on the muscular tone of the seminal vesicle. The contractile response to exogenously administered $\mathrm{ACh}\left(10^{-5}\right.$ to $\left.2 \times 10^{-7} \mathrm{~g} / \mathrm{ml}\right)$ was abolished in the presence of atropine $\left(10^{-7}\right.$ to $\left.2 \times 10^{-7} \mathrm{~g} / \mathrm{ml}\right)$, while the contractile responses to both hypogastric nerve stimulation and exogenously administered ATP $\left(10^{-8} \mathrm{~g} / \mathrm{ml}\right)$ were slightly depressed $55 \%$ (2 experiments) and $41.5 \%$ ( 2 experiments), respectively. The effects of various autonomic agents on the contractile responses of isolated guinea-pig seminal vesicle to hypogastric nerve stimulation and exogenously administered ATP $\left(10^{-6} \mathrm{~g} / \mathrm{ml}\right)$ are summarized in Table 1.

4. Effect of vartous adrenergic $\alpha$-blocking agents on the potentiating effect of $N E$ on the contractile responses to hypogastric nerve stimulation and exogenously administered ATP

As previously described, the contractile responses of the isolated seminal vesicle to

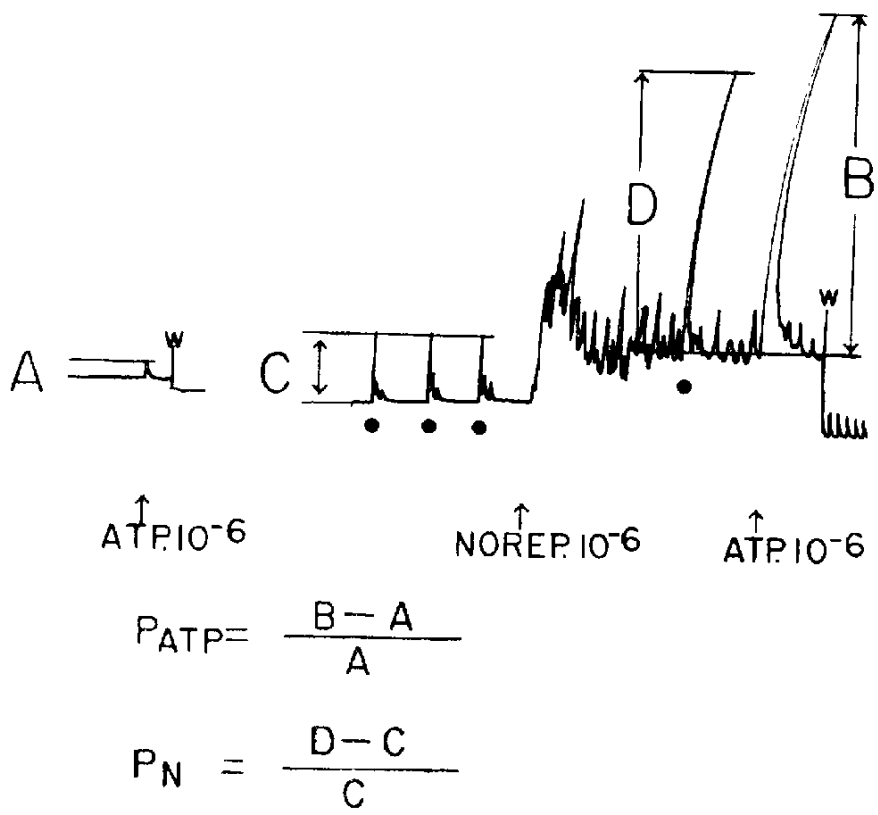

FIG. 4. Potentiating effect of NE $\left(10^{-6} \mathrm{~g} / \mathrm{m} 1\right)$ on the contractile responses of the isolated guinea-pig's seminal vesicle to hypogastric nerve stimulation (O) and exogenously administered ATP $\left(10^{-6} \mathrm{~g} / \mathrm{ml}\right)$. The degree of potentiation of nervemediated contraction $\left(\mathrm{P}_{Y}\right)$ and $\mathrm{ATP}$-induced contraction $\left(\mathrm{P}_{\mathrm{ATP}}\right)$ was compared before and after treatment with various adrenergic $\alpha$-blocking agents. 
TABLE 2. Effects of various adrenergic $\alpha$-blocking agents on the potentiating effect of NE $\left(10^{-3} \mathrm{~g} / \mathrm{ml}\right)$ on the contractile responses of the isolated guinca-pig's seminal vesicle to hypogostric nerve stimulation $\left(\boldsymbol{P}_{\mathrm{Y}}\right)$ and exogenously administered ATP $\left(10^{-6} \mathrm{~g} / \mathrm{ml}\right)\left(\mathrm{P}_{\mathrm{ATP}}\right)$.

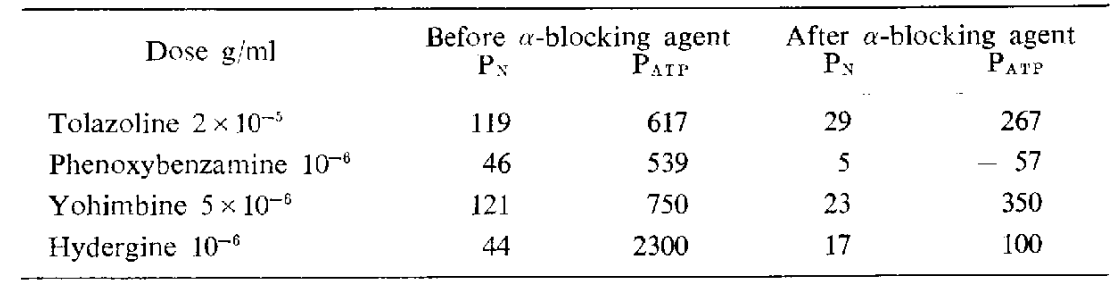

Norepinephrine $10^{-6} \mathrm{~g} / \mathrm{ml}$. ATP $10^{-6} \mathrm{~g} / \mathrm{ml}$.

both hypogastric nerve stimulation and exogenously administered ATP were remarkably potentiated in the presence of NE. Holman and Jowett (30) and Large (31) and Nakanishi et al. (32) have reported that the potentiating effect of NE on the contractile response of the isolated guinea-pig vas deferens was depressed or reversed by adrenergic $\alpha$-blocking agents. The effects of various adrenergic $a$-blocking agents on the contractile responses of the seminal vesicle to hypogastric nerve stimulation and exogenously administered ATP were then tested. The degree of potentiation of nerve-mediated contraction $\left(P_{N}\right)$ and ATP-induced contraction $\left(P_{A T P}\right)$ in the presence of $N E\left(10^{-6} \mathrm{~g} / \mathrm{ml}\right)$ was calculated as shown in Fig. 4. As shown in Table 2, the potentiating effect of NE $\left(10^{-6} \mathrm{~g} / \mathrm{ml}\right)$ on the contractile responses to both hypogastric nerve stimulation and exogenously administered ATP $\left(10^{-6}\right.$ g/ml) were considerably depressed in the presence of various adrenergic $\alpha$-blocking agents, such as tolazoline $\left(2 \times 10^{-5} \mathrm{~g} / \mathrm{ml}\right)$, phenoxybenzamine $\left(10^{-6} \mathrm{~g} / \mathrm{ml}\right)$, yohimbine $\left(5 \times 10^{-6}\right.$ $\mathrm{g} / \mathrm{ml})$ and hydergine $\left(10^{-5} \mathrm{~g} / \mathrm{ml}\right)$. The depressive effect of phenoxybenzamine was not removed even after washing out the preparation, while those of other adrenergic $\alpha$-blocking agents were removed.

5. Effect of reserpine-pretreatment on the contractile responses to hypogastric nerve stimulation and exogenously administered ATP

Animals were treated with reserpine (s.c., $2 \mathrm{mg} / \mathrm{kg}, 24 \mathrm{hr}$ before experiment). Hypogastric nerve stimulation caused a vigorous contraction of the seminal vesicle in the reserpinized animals. Swedin (11) and Wakade and Krusz (14) observed that the "twitch" response of the isolated guinea-pig vas deferens to hypogastric nerve stimulation was scarcely affected with pretreatment of reserpine, although NE content of the organ was depleted, while, Swedin (11) observed that the second phase of contractile response of vas deferens to relatively longer periods of hypogastric nerve stimulation $(30 \mathrm{sec})$ was abolished in the reserpinized animals. In the present study, it was confirmed that the same phenomena was observed in the guinea-pigs seminal vesicle. The effect of ATP in the reserpinized animals was sinilar to that of intact animals. The potentiating effects of NE $\left(10^{-6} \mathrm{~g} /\right.$ $\mathrm{ml}$ ) or $\mathrm{ACh}\left(10^{-7} \mathrm{~g} / \mathrm{ml}\right)$ on the contractile responses of the guinea-pig's seminal vesicle to both hypogastric nerve stimulation and exogenously administered ATP $\left(10^{-5} \mathrm{~g} / \mathrm{ml}\right)$ were also observed in the reserpinized animals (Table 3). The contractile response of 
TABle 3. Potentiating effect of NE $\left(10^{-8}\right.$ to $\left.10^{-6} \mathrm{~g} / \mathrm{ml}\right)$ on the contractile response of the isolated guinea-pig's seminal vesicle to exogenously administered ATP $\left(10^{-6} \mathbf{g} / \mathrm{ml}\right)\left(\mathbf{P}_{\mathrm{ATP}}\right)$ in denervated, intact and reserpinized preparations.

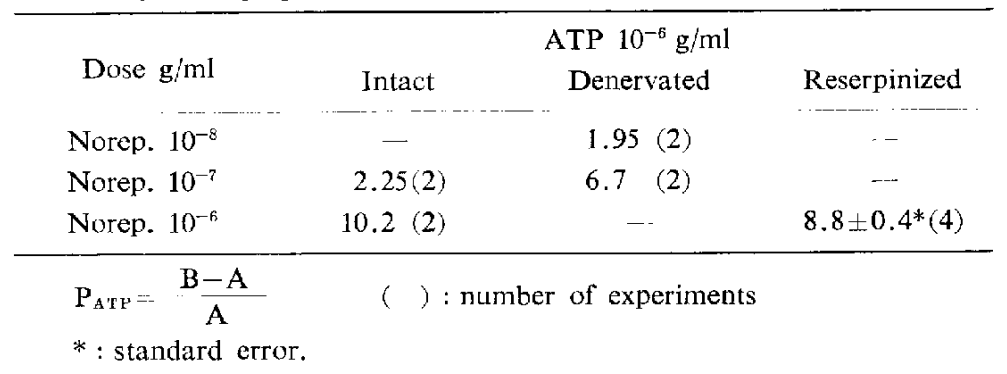

the reserpinized seminal vesicle to hypogastric nerve stimulation was slightly depressed by atropine $\left(10^{-6} \mathrm{~g} / \mathrm{ml}\right)$ (Table 1$)$.

6. Effect of denervation on the contractile responses to exogenously administered NE and ATP

The increase of sensitivity of denervated vas deferens to NE has been reported by several investigators $(26,33-37)$. Furthermore, Kasuya et al. (26), Westfall (33) and Westfall et al. (37) demonstrated the existence of both specific and non-specific denervation supersensitivity in the guinea-pig vas deferens. In the present study, it was also observed that the sensitivity of the denervated seminal vesicle to NE was significantly increased, more than 10 fold, compared with that of the intact seminal vesicle (Fig. 5). The dura-

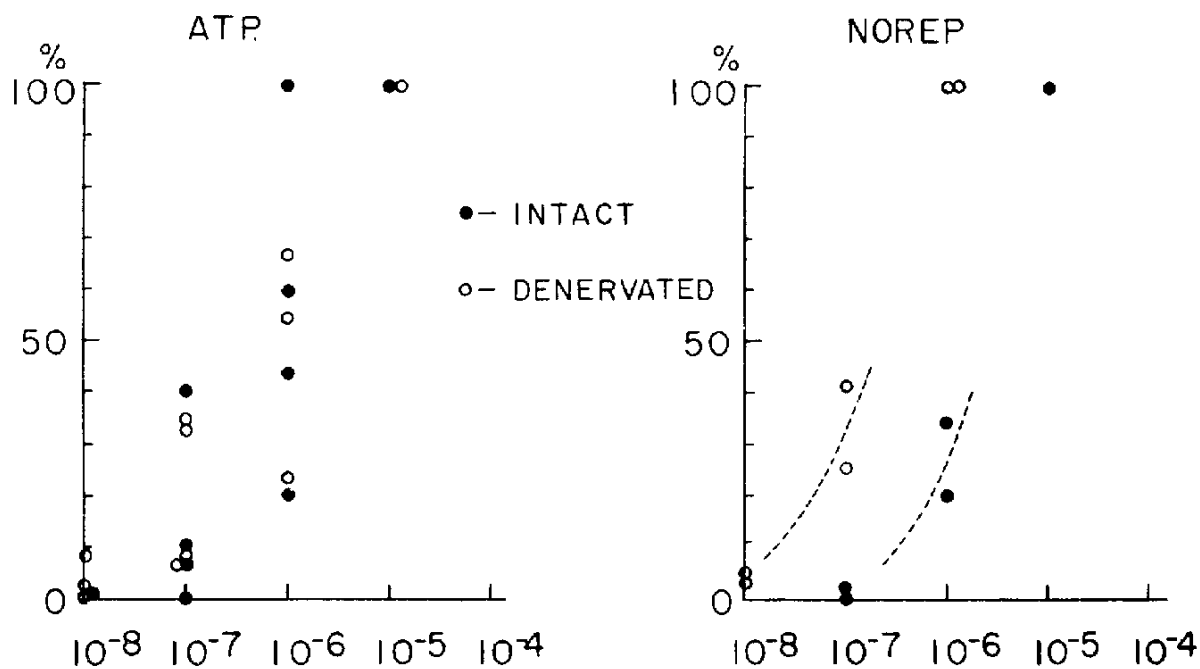

FIG. 5. Left ; Dose-response relationship of ATP in intact (O) and denervated (O) seminal vesicle of the guinea-pig.

Right ; Dose-response curve of NE in intact (O) and denervated (O) seminal resicle of guinea-pig. Denervation increased the sensitivity to $\mathrm{NE}$, but hardly to ATP. 
tion of contraction in response to NE was also prolonged in denervated organs. The denervated seminal vesicle was contracted by the administration of ATP (more than $10^{-7}$ $\mathrm{g} / \mathrm{ml}$ ). The fact that ATP contracts both denervaled and reserpinized organs indicates that ATP acts on post-synaptic membrane directly, but does not act indirectly through the liberation of chemical transmitter from nerve terminals. The sensitivity of seminal vesicle to ATP was almost unchanged by denervation. The non-specific denervation effect was not clearly demonstrated in this study, since the sensitivity to ATP was variable in individual seminal vesides. The potentiating effect of NE on the contractile response 10 ATP $\left(10^{-i} \mathrm{~g} / \mathrm{ml}\right)$ was also observed in the denervated seminal vesicles (Table 3 ). These findings indicate that the interaction between NE and ATP occurs at the post-synaptic membrane.

\section{DISCUSSION}

The contractile response of the isolated guinea-pig vas deferens to hypogastric nerve stimulation was depressed or abolished after treatment of adrenergic neurone blocking agents, such as guanethidine and bretylium $(3,38)$, while the response was generally resistant to adrenergic $\alpha$-blocking agents, such as tolazoline and phenoxybenzamine $(8,9)$. Therefore, Ambache and Zar (13) have argued that the chemical transmitter in hypogastric nerve innervating the guinea-pig vas deferens may not be NE. Swedin (11) and Wakade and Krusz (14) suggested the existence of excitatory agents in hypogastric nerve, besides $\mathrm{NE}$. It seems that $\mathrm{ACh}$ is not a major chemical transmitter in the hypogastric nerve, since the contractile response of the isolated guinea-pig vas deferens to nerve stimulation was almost unaffected by treatment of cholinergic blocking agents such as atropine, tubocurarine and hexamethonium (3, 38). Nakanishi and Takeda (39) pointed out the possibility that ATP is involved in the cxcitatory chemical transmission in hypogastric nerve innervating guinea-pig seminal vesicle, from the result that the contractile responses to both hypogastric nerve stimulation and exogenously administered ATP were dramatically augmented in the presence of $\mathrm{VE}$ as well as in the presence of tolazoline, an adrenergic $\alpha$-blocking agent. Stjärne and Lishajko (17) demonstrated the spontaneous release of NE and ATP from isolated bovine vas deferens and seminal vesicle. Geffin and Livett (40) found that the molar ration of NE to ATP in rat vas deferens particles was 1.3 to 3.7 . Recently, Weinshilboum et al. (41) reported that the stimulation of hypogastric nerve innervating the guinea-pig vas deferens produced proportional release of NE and dopamine $\beta$-hydroxylose. These findings indicate that chemical transmitters are released by the exocytotic process. De Polter et al. (42) have also reported evidence in favour of an exocytotic release mechanism of noradrenaline from the adrenergic neuron.

The present pharmacological study showed that the contractile response of the isolated guinea-pig seminal vesicle to hypogastric nerve stimulation resembled the response to exogenously administered ATP in the presence of NE rather than NE alone. Therefore, if ATP is released by the exocytotic process during nerve stimulation, as well as NE and dopamine $\beta$-hydroxylase, it is likely that the released ATP may play a part as a trans- 
mitter between the hypogastric nerve and seminal vesicle. The fact that the contractile response of the guinea-pig's seminal vesicle to exogenously administered ATP was dramalically augmented in the presence of NE suggests the possibility that a complex of ATP and NE acts as a chemical transmitter. Philippu and Schümann (43) have proposed a scheme regarding the catecholamine-ATP binding form in chromaffin granules. Also, it few investigators have argued that there are catecholamine-nucleotide complexes in adrenal medulla $(16,44)$ and sympathetic nerve trunk $(15)$. On the other hand, interaction of catecholamine with ATP at the adrenergic $\alpha$-receptor site has been postulated by Belleau (45) and Bloom and Goldman (46). The latter have proposed that catalytic enzymatic hydrolysis of ATP in the presence of catecholamine may produce $\alpha$-excitation (dynamic receptor hypothesis). The possibility remains that other nucleotides, such as adenosine diphosphate (ADP) and adenosine monophosphate (AMP) are chemical transmitters. This may be ruled out, however, since ${ }^{3} \mathrm{H}$-adenosine taken up into purinergic nerve is storcd mostly as ${ }^{3} \mathrm{H}$-ATP, with only a trace of ${ }^{3} \mathrm{H}$-ADP detectable (19). Also, ATP has the greatest sensitivity in the intestines and urinary bladder, compared with olher nucleotides, and cyclic AMP was inactive in the bladder (22). Post-ganglionic denervation of hypogastric nerve increased sensitivity to NE, but not to ATP. It appears that NE is taken up into the nerve terminals after termination of the transmitter-function, while ATP is hydrolyzed at the receptor site, like acctylcholine at cholinergic receptor. The released NE may not be degraded by catechol-0-methyl transferase between hypogastric nerve terminals and the receptor site in the guinea-pig's seminal vesicle (7). The present study cannot exclude minor cholinergic control in the guinca-pig's seminal vesicle, since ACh and physostigmine enhanced the contractile response to hypogastric nerve stimulation, while atropine slightly depressed the response in both intact and reserpinized animals.

Acknowledgement: The authors wish to thank Professor Carl Wood (Department of Obstetrics and Gynecology, Monash University, Melbourne, Australia) for kind advice and criticism of the manuscript.

\section{REFERENCES}

1) Hukovic, S.: Br. J. Pharmacol. Chemother. 16, 188 (1961)

2) Burnsiock, G. and Holman, M.E.: J. Physiol. 160, 461 (1962)

3) Bentlei, G.A. And SAbinf, J.R.: Br. J. Pharmacol. Chemother. 21, 190 (1963)

4) Burnstock, G. Avid Holmax, M.E.: Br. J. Pharmacol. Chemother. 23, 600 (1964)

5) Falck, B., Owmà, Ch. and Suöstrand, N.O.: Experientia 21, 98 (1965)

6) Nakanishi, H. Ald Takeda, H.: Japan. I. Pharmacol. 15, 199 (1965)

7) Nakanishi, H., Doteuchi, M., Otait, K., Tanaka, H. and Takeda, H.: Japan. J. Pharmacol. 19, 535 (1969)

8) Boyd, H., Chava, V. ANi Ra\d, M.J.: Br. J. Pharmacol. Chemother. 15, 525 (1960)

9) Ohlin, P. and Strombland, B.C.R.: Br. J. Pharmacol. Chemother. 20, 299 (1963)

10) Nakanishi, H., Doteuchit, M. and Takeda, H.: Japan. J. Pharmacol. 20, 61 (1970)

11) Swedin, G.: Acta physiol. scand. Suppl. 369, 1 (1971)

12) Owman, Ch. and S.östrand, N.O.: Experientia 12, 759 (1966)

13) Ambache, N. And Zar, M.A.: J. Physiol. 216, 359 (1971)

14) WAK 1 Dr, A.R. A\D KRusz, J.: J. Pharmacol. exp. Ther. 181, 310 (1972)

15) Lagercravtz, H.: Acta physiol. scand. Suppl. 366, 1 (1971) 
16) Pai, V.S. and Maynert, E.W.: Mol. Pharmacol. 8, 82 (1972)

17) SiJ̈̈rne, L, ANd Lisha.jKo, F.: J. Neurochem. 13, 1213 (1966)

18) Burnstock, G., Champbell, G., Satchell, D. and Smythe, A.: Br. J. Pharmacol. Chemother. 40,668 (1970)

19) Su, C., Bevan, J.A. A.vi Burnstock, G.: Science 173, 336 (1971)

20) Dumsday, B.: J. Pharm. Pharmacol. 23, 222 (1971)

21) Burnstock, G., Dumsday, B. and Surrhe, A.: Br. J. Pharmacol. Chemother. 44, 451 (1972)

22) Burystock, G.: Pharmacol. Rev. 24, 509 (1972)

23) Westwood, D.A. and Whaler, B.C.: Br. J. Pharmacol. Chemother. 33, 21 (1968)

24) SJöstrand, N.O.: Acta physiol. scand. 54, 463 (1962)

25) Ferry, C.B.: J. Physiol. 192, 463 (1967)

26) Kasuya, Y., Goto, K., Hashimoro, H., Watanabe, H., Munakata, H. and Watanabe, M.: Europ. J. Pharmacol. 8, 177 (1969)

27) Bhagat, B. And Zeidman, H.: Am. J. Physiol. 219, 691 (1970)

28) Della Bella, D., Benelli, G. and Gandini, A.: J. Pharm. Pharmacol. 16, 779 (1964)

29) Bharghya, K.P., Kar, K. and Strevdra, S. Parmar: Br. J. Pharmacol. Chemother. 24, 641 (1965)

30) Holman, M.E. and Jowett, A.: Alust. J. exp. Biol. 42, 40 (1964)

31) Large, B.J.: Br. J. Pharmacol. Chemother. 24, 194 (1965)

32) Nakasishi, H., OKegawa, T. and Shimamoto, K.: Japan. J. Pharmacol. 16, 10 (1966)

33) Westeall, D.P.: Br. J. Pharmacol. Chemother. 39, 110 (1970)

34) Otawa, H. and Sugawara, K,: Europ. J. Pharmacol. 11, 56 (1970)

35) Birmingham, A.: J. Physiol. 206, 645 (1970)

36) Moraes, S. De., Carvalho, F.V. and Welirle, R.D.: J. Pharm. Pharmacol. 22, 717 (1970)

37) Westfall, D.P., McClurl, D.C. and Fleming, W.W.: J. Pharmacol. exp. Ther, 181, 328 (1972)

38) Brrmingifam, A.T. And Wilson, A.B.: Br. J. Pharmacol. Chemother. 24, 375 (1963)

39) Naka.nishi, H. ANd Takeda, H.: Japan. J. Pharmacol. 22, 269 (1972)

40) Geffin, L.B. and Livett, B.G.: Physiol. Rev. 1, 98 (1971)

41) Weinshilboum, R.M., Thoa, N.B., Johnson, D.G., Kopin, I.J. and Axelrod, J.: Science 174, 1349 (1971)

42) De Potter, W.P., Chubb, I.W. and De Schaffdryver, A.F.: Arch. int. Pharmacodyn. Thér., Suppl. 196, 258 (1972)

43) Philipeu, A. and Schümann, H.J.: Arch. exp. Path. Pharmakol. 252, 339 (1966)

44) Wejver, N. and Jardetzky, O.: Arch. exp. Path. Pharmakol. 248, 308 (1964)

45) Belleau, B.: Pharmacol. Rev. 18, 131 (1966)

46) Bloom, B. and Goldman, I.M.: Advances in Drtg Research, Edited by HarpF.r, N. AND Simuonds, A., Vol. II, Academic Press, Inc., London. (1966) 